\title{
ESTABLISHING A MODERATE RELIGIOUS ACADEMICS IN PESANTREN-BASED HIGHER EDUCATION
}

\author{
Ahmad Royani \\ State Islamic Institute of Jember \\ Email: royanpuritanjung@gmail.com
}

\begin{abstract}
Pesantren is an ideal partner for the government to jointly improve the quality of education as a basis for implementing social transformation. It provides qualified human resources with good morals emphasizing moderate religious values that reflect within the Islamic value of rahmatan lilalamin. This paper wants to see pesantren-based universities in giving birth to moderate religious academics. By taking the object of study Nurul Jadid university, which is a high miscarriage based pesantren. This research applied a descriptive study by using a qualitative approach. The research participants were Islamic scholars (kyai), lecturers, and students at the University of Nurul Jadid. Data were collected through interviews, observation, and documentation. This study showed that establishing the Islamic boarding school culture produced mod erate religious academics at Nurul Jadid University. It was by implementing the supremacy of kyai's preaching and teaching (dawuh kyai). It was constructed through artifacts, values, and assumptions emphasizing moderate religious aspects.
\end{abstract}

Abstrak: Pesantren menjadi partner yang ideal bagi pemerintah untuk bersama-sama meningkatkan mutu pendidikan sebagai basis bagi pelaksanaan transformasi sosial melalui penyediaan sumber daya manusia yang mumpuni dan berakhlakul karimah yang menekankan nilai-nilai religius moderat yang mencerminkan nilai Islam rahmatan lilalamin. Tulisan ini ingin melihat perguruan tinggi berbasis pesantren dalam melahirkan akademisi religius moderat. Dengan mengambil objek kajian Universitas Nurul Jadid yang merupakan perguran tinggi berbasis pesantren. Penelitian ini menggunakan pendekatan kualitatif dengan rancangan studi kasus. Teknik pengumpulan data menggunakan wawancara mendalam,observasi partisipatif dan studi dokumen. Data-data yang yang terkumpul kemudian dianalisis secara simultan, dengan teknik: pengumpulan data, kondensasi data, penyajian data, dan penarikan kesimpulan. Hasil 
penelitian ini menemukan konstruksi budaya pesantren dalam melahirkan akademisi religius moderat di Univesitas Nurul Jadid dilakukan dengan kekuatan dawuh kyai yang di konstruksi melalui artifak, nilai, dan asumsi yang mengedepankan aspek religius moderat

Keywords: pesantren; higher education; moderate religious academics.

\section{INTRODUCTION}

The emergence of Islamic higher education with pesantren characteristics such as establishing universities, institutes, and higher education in the Islamic boarding school environment is evidence of the transformational pesantren. ${ }^{1}$ The transformation of pesantren education in formal educational institutions and the perspective of learning are inseparable from its function. It creates a civilized and dignified generation to protect the unitary state of the Republic of Indonesia. Pesantren has become an enlightening preaching institution for having a tolerant and peaceful approach to Islam. ${ }^{2}$ Badrus Sholeh said that Islamic boarding schools had become the driving force for a tolerant and peaceful tradition. It is also the first step to developing the peaceful culture from the pesantren community, which receives broad support from the general public and inherently has become part of government policies. ${ }^{3}$

Research conducted by Akmal Mundiri, Afidatul Bariroh revealed that transinternalization of character formation through the trilogy and the five awareness of santri at Nurul Jadid Islamic Boarding School, Paiton, Probolinggo has seen in the following: 1) the daily activities of students in the form of congregational prayer, the implementation of the diniyah and formal school, FKS activities, the existence of pesantren's regulations, the obedience (ta'dzim) of students towards kyai and as atidz (teachers), such activity comprises the values of the trilogy and the five awareness of santri; 2) The media used in the internalization process is also actualized by the behavior of a kyai who becomes a role model

1 Pesantren-Based Universities are higher education institutions in pesantren which has pesantren character. In 2015, the data of the Ministry of Religion showed that there were 13 pesantren-based universities. In East Java, there are UNUJA, UNUDA, Universitas Ibrahimy. Universitas Pesantren Darul 'Ulum, Jombang, Universitas Islam Darul Ulum Lamongan.

2 Mohamad Fahri and Ahmad Zainuri, "Moderasi Beragama di Indonesia” 25, no. 2 (2019): 6 .

3 Badrus Sholeh, Budaya damai Komonitas Pesantren, 1 (Jakarta: LP3ES, 2007) vii. 
in the pesantren. ${ }^{4}$ Nurhayati Abdul Hamid also suggested that schools have designed and devel o ped programs to prevent radicalism. Efforts made by schools incorporate such as selecting textbooks, developing learning modules and manuals of Isl a mic Education by teachers, and maintaining activities related to nationalism. This strategy is implemented through Islamic Education learning both inside and outside the classroom. In the classroom context, the learning process in cludes realizing the objectives, implementing materials, media, methods, and evaluation of the learning process. Likewise, the learning process outside the classroom includes some activities related to extracurricular activities, religion, and nationalism. ${ }^{5}$

The data taken from the Ministry of Religion 2019 shows that universities are also has become an easy target for radicalism. Some universities like UI Jakarta, IPB, ITB, UGM Yogyakarta, UNY, Unibraw Malang, Unair, Unram, UIN Jakarta, and UIN Bandung have been exposed to radicalism from a religious perspective. The radicalization of public campuses or Islamic-based campuses continues to show an uptrend. ${ }^{6}$ Even some intellectual circles were lulled by the political struggle agenda of radical Islam in the form of the implementation of Islamic syari'at. BNBT and BIN research showed that the same figure, 39\% of students from 15 provinces, is recorded to be interested in radicalism. ${ }^{\text {? }}$

Nurul Jadid University, Paiton Probilinggo, is an institutionally pesantrenbased higher education born from pesantren's idealism. It has a big vision in internalizing the values of pesantren to students. In the early days, Nurul Jadid University was initially the result of deliberation from the Islamic scholars of NU in Lumajang in 1968. It was intended to establish an academy that aimed to produce da'wah and educational cadres. ${ }^{8}$

4 Akmal Mundiri and Afidatul Bariroh, "Trans Internalisasi Pembentukan Karakter Melalui Trilogi Dan Panca Kesadaran Santri,” Jurnal Iqra': Kajian Ilmu Pendidikan 3, no. 1 (2018): 24-55.

5 Abdul Hamid, Amran Mahmud, and Aldiawan Aldiawan, "Strategi Dosen Pendidikan Agama Islam dalam Mencegah Ekslusivitas dan Radikalisme Pada Kegiatan Keagamaan Mahasiswa," Halaqa: Islamic Education Journal 3, no. 2 (January 7, 2020): 75, https://doi. org/10.21070/halaqa.v3i2.2724.

6 "Fadly et al. - 2020 - Diagnostic Skill of Internalization-Interconnectio.Pdf," n.d.

7 Uun Yusufa and Amal Khusna, Penguatan Ma'had al Jamia'ah Sebagai Agen Pengarus Utamaan Moderasi Islam Bagi Santri Di IAIN Jember (Jember: IAIN Jember, 2018).

8 Achmad Fawaid, Kaleidoskop Pondok Pesantren Nurul Jadid, (Probolinggo: Pustaka Nurja, 2019). 
Through higher education, the pesantren's alumni are expected to continually develop their knowledge in the Islamic educational field and other scientific fields, such as economics, social science, technology, humanities, and the pure sciences. Something left to do within the pesantren's development at this particular moment and future, where the dynamics of society is progressing rapidly. It is how to make the pesantren compete and produce a 'plus' Islamic academics who are exceptionally intelligent because such Islamic academics are $\mathrm{w}^{9}$

In their development, Islamic boarding schools underwent a significant transformation process, especially in the development of formal education, in this case, the development of universities. Kyai, as the chief in command, of course, in the aspect of the development of formal educational institutions, aspire to be able to transform the values of Islamic boarding schools into formal educational institutions. In addition to kyai as the chief, the existence of teachers and lecturers at the institution gives some color to the values of the pesantren. Then, they are developed in higher education to produce cadres with pesantren's characteristics and rahmatan lil alamin based intellectual who has been served as the fundamentals for moderate religious academics or scholars. Thus, the

9 Ahmad Royani, "Eksistensi Pendidikan Pesantren dalam Arus Perubahan," Cendekia: Jurnal Kependidikan Dan Kemasyarakatan 16, no. 2 (November 22, 2018): 387, https:// doi.org/10.21154/cendekia.v16i2.1242.precisely, and adaptively. This paper talks about the existence of boarding school education in dealing with the current change. This research is focused on the existence of which is done by al-Syafi'i in the current changes. The method used in this research is a case study in boarding school, namely al-Syafi'i Boarding School in maintaining its existence as an Islamic boarding school institution. This study uses a theory presented by Talcott Parsons, which states that when the social organization systems want to maintain their existence, they must have four things called AGIL: Adaptation, Goal attainment, Integration, and Latency. This study concludes that the exsistence of the boarding school education in the current change is as follows; First, the adaptation carried out by the al-Syafi'i boarding school was to find out the current needs of the community. Second, personality development aims to prepare students and the community to have religious knowledge and general science in order to become human beings that is capable of practicing their knowledge. Third, the integration of public school and boarding school systems to produce a generation that is reliable in their fields. Fourth, the pattern applied by the al-Syafi'i boardingschool is to establish communication with all components, i.e. the community, parents of students and the government, to build and provide schools. In addition, social investment is an activity of the al-Syafi'i boarding school which aims to create a generation that is independent and useful in future social life.","containertitle":"Cendekia: Jurnal Kependidikan Dan Kemasyarakatan”,"DOI":"10.21154/cendekia. v16i2.1242","ISSN":"2477-796X, 1693-1505","issue":"2","journalAbbreviation":"Cendekia J. Education and Society","language":"id","page":"387","source":"DOI.org (Crossref 
author wants to explain how Universities based pesantren give birth to moderate religious academics with the rahmatan lil alamin character.

\section{METHOD}

This research was a descriptive study. It employed a qualitative approach. It was a descriptive study, for it aimed to create a depiction of a situation or event of the establishment of moderate religious academics in Islamic boarding schools. It is in line with Nazir. He says that descriptive research aims to make a picture of a situation or event so that the intention to carry it out is a mere accumulation of primary data. ${ }^{10}$ This research was conducted at Nurul Jadid University.

Data collection techniques used in this study were interviews, observation, and documentation. Interviews were used to gather data or information related to the process of establishing a moderate religious culture. Besides, observation was used to obtain data on artifacts, values, and assumptions built in establishing moderate religious academics. Documentation was used to obtain data regarding the description of the object under study. Moreover, the documentation was used to complement the data from interviews and observations. To obtain data that could be scientifically accounted for from the data that has been collected, its validity must be checked first. In this study, the data validity checking technique used was the triangulation technique which is the technique of crossing information obtained from the source. In the end, only valid data was used to achieve the research results. ${ }^{11}$ The triangulation technique was used in this research. It reconfirmed the interview information with documentation and observation. Research data obtained from different sources through interviews were reconfirmed with data obtained through observation and documentation. The data used in this study were considered valid for it had gone through crossing information. The data analysis technique used in this research was the inductive analysis technique that started from the data and led to general conclusions.

\section{THEORETICAL FRAMEWORK}

The manifestation of organizational culture at the values level is a value used as a reference for all decisions and actions within the organization's members,

${ }^{10}$ Nazir, Metode Penelitian (Jakarta: Ghalia Indonesia, 2005.)55

11 Suharmi Arikunto, Prosedur Penelitian: Suatu Pendekatan Praktek, 1st ed. (Jakarta: Rineka Cipta, 2006). 18 
reflecting the objectives, identities, and standards of valuation for every aspect. ${ }^{12}$ While the manifestation of organizational culture at the assumption level is the standpoint of organizational members about themselves and others which leads to the relationship between themselves and other people they live with.

Edgar H. Schein illustrates that organizational culture is a pattern of basic assumptions that a group has found, determined, and developed through the learning process, external group adaptation, and internal group integration. That assumption has worked well enough to become valid because it is taught to the new members to instill understanding, thoughts, and feelings related to organizational problems. ${ }^{13}$

From the perspective of Mujamil Qomar, he explained that four things must be considered within the educational progress, such as growth, change, renewal and development, sustainability, and resilience. ${ }^{14}$ Meanwhile, Talcott Parsons argues that for the social organization system to survive, the system must have four things called AGIL: ${ }^{15}$ adaptation, which means the system must adapt to the environment and adapt the environment itself to the needs; goal attainment (have a goal), that is, a system must define and achieve its primary goals; integration (integration), which means a system must regulate the relationship between the parts that become its components; and latency (maintenance pattern). In this case, the resilience of pesantren is due to the uniqueness of the life pattern as a subculture. Furthermore, it is also due to the Javanese culture, which involutes and emphasizes harmony so that it absorbs culture from outside without losing its identity.

The adaptation of the pesantren itself is carried out holistically and consistently (istiqoma) within the role of the leader; in this case, kyai becomes an adaptive and revolutionary figure in perceiving social developments in society. ${ }^{16}$ The two pesantren educational institutions aim to create a generation

12 Wirawan Fadly et al., "Diagnostic Skill of Internalization-Interconnection Qur'ani With Science in Three Levels of Madrasah," Cendekia: Jurnal Kependidikan Dan Kemasyarakatan 18, no. 2 (December 10, 2020): 267-89, https://doi.org/10.21154/cendekia.v18i2.2178. 1992).

13 Edgah H Schein, Organizational Culture and Leadership (San Fransisco: Jossey Bass Inc,

14 Mujamil Qomar, Manajemen Pendidikan Islam, (strategi Baru Manajemen Pendidikan Islam), (Jakarta: Erlangga, 2007).47

15 George Ritzer, Teori Sosiologis Modern (Jakarta: Prenada, 2004).121

16 Royani, "Eksistensi Pendidikan Pesantren dalam Arus Perubahan."precisely, and adaptively. This paper talks about the existence of boarding school education in dealing with the current change. This research is focused on the existence of which is done by al-Syafi' $i$ 
with pesantren characteristics with morals and maturity in society. ${ }^{17}$ In addition, looking at the development of the era, cultural integration with the philosophy of taking care of old traditions and using new traditions considered to be better and more beneficial has been carried out. Another aspect is establishing a pesantren institution Nurul Jadid, which has allowed discussion within the development of pesantren institutions. The two institutions established formal education from elementary to tertiary level to show some progress in the development. The pattern adopted in the two institutions is to build the nuances of characteristics of pesantren-based higher education.

\section{FINDINGS AND DISCUSSION}

\section{Islamic Boarding School Cultural Construction in Establishing Moderate Religious Academics}

The artifact existed in realizing moderate religious academics at Nurul Jadid University are manifested through physical buildings, strengthening language, the use of technology and artistic creation products, stories about the founders and the masyayikh of the pesantren who are brought to life, ways in decreasing anger, and joint activities related to moderate religious culture.

\footnotetext{
in the current changes. The method used in this research is a case study in boarding school, namely al-Syafi'i Boarding School in maintaining its existence as an Islamic boarding school ins titution.This study uses a theory presented by Talcott Parsons, which states that when the social organization systems want to maintain their existence, they must have four things called AGIL: Adaptation, Goal attainment, Integration, and Latency. This study concludes that the exsistence of the boarding school education in the current change is as follows; First, the adaptation carried out by the al-Syafi'i boarding school was to find out the current nee $\mathrm{d} s$ of the community. Second, personality development aims to prepare students and the community to have religious knowledge and general science in order to become human beings that is capable of practicing their knowledge. Third, the integration of public school and boarding school systems to produce a generation that is reliable in their fields. Fourth, the pattern applied by the al-Syafi'i boardingschool is to establish communication with all components, i.e. the community, parents of students and the government, to build and provide schools. In addition, social investment is an activity of the al-Syafi'i boarding school which aims to create a generation that is independent and useful in future social life.","containertit 1 e":"Cendekia: Jurnal Kependidikan Dan Kemasyarakatan","DOI":"10.21154/cendekia. v16 i 2.1242","ISSN":"2477-796X, 1693-1505","issue":"2", journalAbbreviation”:"Cendekia J. Education and Society","language":"id","page":"387”,"source”:"DOI.org (Crossref

17 HA Rodli Makmun, "Pembentukan Karakter Berbasis Pendidikan Pesantren: Studi Di Pondok Pesantren Tradisional Dan Modern Di Kabupaten Ponorogo," Cendekia: Jurnal Kependidikan Dan Kemasyarakatan 12, no. 2 (2016): 211-38.
} 
First, the physical construction of the Nurul Jadid Islamic boarding school itself has developed quite significantly. Nurul Jadid improves and renovates the existing buildings, office buildings, dormitories, madrasah, and college buildings from year to year. The primary colors of the existing buildings in the pesantren are yellow, blue, green, and white. Based on the observations, it can be seen that the physical activities in Nurul Jadid are designed by emphasizing the values of pesantren. The higher educational institution is located outside the central Islamic boarding school, aiming to provide free space for students as university students in general. KH. Abdul Hamid Wahid explained in the interview that the physical buildings in the pesantren and universities are based on the values of the pesantren's values. The manifestation of all of this is to build students' religious attitudes by building a prayer room (musholla) in the university environment. Moreover, to develop students' critical thinking process, the Student Activity Unit (UKM) office was also built. The building for the university students (POMAS) within the pesantren's environment is also a facility provided by the pesantren in the context of the internalizing process of the pesantren's values to students daily.

Second, in terms of language, Nurul Jadid Islamic boarding school does not oblige the use of a particular language daily. According to the results of an interview with Alief Hidayatullah, who is a POMAS administrator, he explained that students in Nurul Jadid are free to use their respective regional languages. The essential thing in the language itself is courtesy within the norms and values in speaking. It is a form of the tasammuh concept carried out by the pesantren to appreciate the differences between students. But when the students registered as members of the Arabic and English area, students must follow the existing rules. On the Unuja campus itself, language is free, but the students need to be aware of the existing ethics. The use of Madurese language is the one that students in everyday life often use. But in formal languages, Indonesian, English, and Arabic are used.

Third, the use of technology and products of aesthetical creations. From the educational system, Nurul Jadid Islamic boarding school is a salafiyah-based Islamic boarding school. This boarding school has used modern technologybased management. The use of information technology can be seen from the equipment provided, such as internet networks to facilitate students, to be outdated. All students can access the internet through their students' number ID. Something that worth mentioning is that the supervised patterns of pesantren in 
overseeing the contents accessed by students that are, in this case, recorded by the Data and Information System Center (PDSI). Institutionally, Unuja is the first Islamic boarding school to obtain ISO certification for two categories at once, namely ISO 9001: 2015 for Quality Management Systems and ISO 21001: 2018 for Educational Organization Management Systems.

Fourth, the stories fostered in everyday life in realizing moderate religious academics are strengthened through several things. Among them are stories about exemplary acts performed by kyai. The bulletin in each edition always describes the pesantren's leaders from the early ones, KH. Zaini Mun'im was a figure breaking down the invaders up to Kyai H. Zuhri Zaini, a humble and popular figure. Apart from that, the institutional aspects developed and internalized in the pesantren cannot be separated from the institutional system built. Pesantren with a solid managerial system will provide a robust control system in everyday life within the pesantren itself or college environment.

As illustrated by the story of KH Zaini Mun'im, the founder of the Nurul Jadid Islamic Boarding School, he succeeded in changing the conditions of the Karanganyar Village. It was previously rife with crime into one of the most prominent Islamic religious centers in Java. The same thing happened through his successors, KH Hasyim Zaini, the eldest son of KH Zaini Mun'im, a significantly important figure in promoting Islamic preaching in Paiton is Nurul Jadid Islamic Boarding School. The next kyai who continued the mandate in Nurul Jadid also displayed exemplary personas. One of them is depicted in the stories fostered by the Nurul Jadid masyayikhs. It can be summed up in the term 'jimat asli' (the actual charm), namely the value of istiqomah (consistency), independence, trustworthiness, firm, appreciation, solution, nobility, and integrity. The role models of kyai who have driven the Nurul Jadid Islamic boarding school since its establishment until now can be instilled through some behaviors daily. Thus, norms are not only conveyed orally but also exemplary. From the concept of 'jimat asl", Nurul Jadid's students can have a well-defined attitude in religion. It is without denying the insight of diversity as well as creative, productive, and disciplined power. Furthermore, in the process of internalization in educational institutions under the auspices of the Foundation (Nurul Jadid), from basic to higher education, these jimat asl values must be incorporated into learning.

Fifth, in showing the emotions of the pesantren, they are represented by institutions. Responsive emotions are manifested in a formal attitude both in writing and strong arguments based on the aspect of naqli (Al-Qurran and Al- 
Hadith). The manifestation of the emotion is revealed within moderate religious values. The rules made are based on the aspects of the pesantren's vision and mission inscribes in the trilogy and the five awareness of santri.

Sixth is the joint activities related to moderate religious culture. Among them; 1) reading tawassul and praying to the book's author when reading AlQuran or the learning process in college. The purpose of tawassul is for students to be given ease and blessing in learning and gain knowledge. 2) lecture on the subject of Sufism character taught directly by Kyai Zuhri Zaini. It is a routine activity carried out by the University Student Islamic Boarding School (POMAS) to build students' spiritual strength. In the Pomas's documentation, it is explained that this activity is carried out once a month at the beginning of each month with a schedule that the board has made of the Student Islamic boarding school. 3) Reading tahlil every Friday night. This activity is carried out to strengthen the religious culture of students. According to Alief Hidayatullah, this is a routine activity that aims to strengthen religious culture among students. 4) Apart from that, the pesantren also conducts a distinct hataman and istigosah between alumni and sympathizers from various regions devoted to praying for the early leaders of the pesantren who were passed away. 5) transmission through 'kitab kuning' (Islamic guidance books). It is held from 07.00-09.00 am, commonly known in elementary to intermediate institutions as diniyah. Meanwhile, as for university students, it is known as LIK. The study of the 'kitab kuning' referred to is an attempt to scientifically strengthen students' knowledge and maintain the sanad (the continuation of the learning process) by reading a book written by KH. Zaini Mun'im and the masyaikhs. 6) outing and haul traditions. The ziarah (outing) tradition has been built by the masyaikhs to honor someone who had been passed away. It is a tradition of Islamic boarding schools and Indonesian society to realize honor for someone who had passed away. In the Nurul Jadid Islamic boarding school itself, the ziarah tradition is considered a daily activity of the students to gain the blessing of the founder who has established the boarding school. 


\section{Trilogy and the Five Awareness of Santri; Manifestation of a Strong Value Construction}

The ethical values summarized in fiqh and organization, as described in the trilogy of Nurul Jadid's students, are:

$$
\text { الاهتمام با لفروض العينية, الاهتمام بترك الكبائر, حسن الادب مع اللّ ومع الخلق }
$$

"Paying attention to the obligations of fardhu ain, be introspective by leaving major sins behind, serving God and being virtuous towards others."

Then framed with the five awareness of santri, as follows:

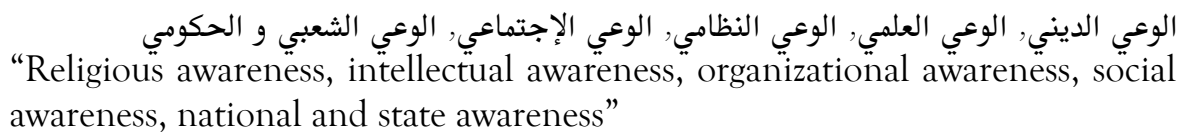

First, religious awareness includes three aspects, namely aqidah (faith and belief), ibadah (the act of worship), and akhlak (morals). Aqidah is a fundamental quality that must be retained by every student of Nurul Jadid Islamic boarding school. When the aspect of aqidah is vital, then it leads to a strong faith. Moreover, when the faith is strong, it is manifested in the ibadah or the act of worship. This particular aspect (ibadah) is divided into two. They are mahdhah/ muqayyadah worship (formal, bound by certain conditions and requirements), and ghairu mahdlah/muthlaqah (non-formal, the applicative aspect which is not bound by certain conditions and requirements). The act of Mahdhah worship consists of four pillars apart from the shahada of the five pillars of Islam; prayer, fasting, zakat, and hajj. Besides, a ghairu mahdhah worship is a worship other than mahdhah, such as practicing religious activities as once practiced by the Prophet Muhammad, both fasting and others. The highlight point on the aspect of ibadah is also contained in the three criteria for students, especially in the first one who pays attention to fardlu 'ain (individual obligation). The third aspect is akhlak, or morals. This aspect aims to shape the students' personality and behavior to conform to Islamic morality and values. The aspect of ihsan here is divided into two: morals and manners. The aspect of morals is manifested in the heart. It consists of intentions, thoughts, and qualities that aim for good deeds and glory. Meanwhile, manners are the actualization of morals and character as seen from human attitudes and behavior. This aspect of morality is not the only concern for individual matters, but also social ones, such as social order, amar ma'ruf nahi mungkar and ethical norms in the family, and so forth.

The second is intellectual awareness. Knowledge, by definition, means knowing the unknown (idrakul majhul) or something that is not yet known. 
As beings that Allah SWT gives an intellectual capacity, humans are required to seek knowledge to equip themselves in pursuing the path of life. Without knowledge, you will undoubtedly experience so many difficulties in the journey of life. Therefore, the prophet Muhammad SAW said: "seek knowledge from the parents' swing to enter the lahat" and "seek knowledge even if you have to go to China." Knowledge is divided into two, namely religious knowledge and worldly science. The students are expected to know and comprehend these two knowledge. Furthermore, the awareness of worldly science must be integrated with the awareness of religious knowledge. The most known term is integrating science and technology (science and technology) with faith and piety. Thus, the students are expected to be Muslim scientists or scientists having solid Islamic values.

Third, through social awareness, pesantren and the students are expected not to be the 'ivory towers,' far from the community. Pesantren and the students must be able to blend in with society. It means that pesantren is part of society. Thus, it can be said that pesantren belongs to society and vice versa. Therefore, there is no gap between pesantren and their students as well as with the community. When such a condition is met, all kinds of pesantren's activities will be supported by the whole community. Well, it is the responsibility of the pesantren, born from the midst of society, to carry out transformation and emancipation so that society can advance, both in civilization and at the social level.

Fourth, the philosophical foundation that underlies KH. Zaini Mun'im to formulate the fourth concept of the awareness within students, especially for the awareness of the nation is the word of Allah SWT: "In fact, we created all of you from male and female types. And we created all of you from the tribes to know each other". Besides, the Prophet Muhammad SAW also mentioned that the act of love for the homeland includes proof of faith, which is also the basis for formulating the concept of this fourth awareness, which is national and state awareness.

Fifth, apart from Kyai Zaini's concern for the existence of Muslims, organizational awareness was formulated and originated from his experience at the Jam'iyah Nahdlatul Ulama (NU) from 1952 to 1972. In the organization itself, apart from his effort to advance his organization through brilliant thoughts and ideas, he also consistently holds ethics and morality in organizations. 
From the five awareness of santri mentioned, it can be said that the essence within the strengthening process of moderate religious value is the equality of profane and ukhrowivalues. The supervising phase is carried out equally between values and attitudes, knowledge, intelligence, skills, communication abilities, and awareness of environmental ecology. In other words, it concerns the equality between IPTEK (science and technology) and IMTAK (faith and piety), which includes IQ, EQ, and SQ.

The Values of Sincerity and Islamic Ideology of Ahlus-sunah wal Jamaah: a Manifestation of the Moderate Religious Values' Supremacy

The basic assumptions underlying santri and university students to have moderate religious attitudes include: First, self-confidence. This belief is held firmly, especially by students and university students. It is the act of sincerity and devotion to the pesantren. It holds tightly to the trilogy and the five awareness of santri that they will become successful people in society. The two Islamic ideologies are ahlus-sunah wal jamaah as a form of moderation. In terms of producing moderate religious academics, of course, it cannot be separated from the trilogy value and the five awareness of the santri. Besides, NU's building configuration supremacy is the masyaikhs who provides the faculty to internalize the value of rahmatan lil alamin.

Table 1. Maqosidus Syaria'ah within the Aswaja's Framework

\begin{tabular}{|c|c|c|}
\hline $\begin{array}{l}\text { Maqosidus } \\
\text { syaria'ah }\end{array}$ & Liberalism & Aswaja-ism \\
\hline Hifd Al Mal & $\begin{array}{l}\text { To improve the welfare of the } \\
\text { people, to justify interest-rate }\end{array}$ & $\begin{array}{l}\text { The improvement of welfare needs to } \\
\text { apply the value of tawassut and adl so } \\
\text { that there is no need to justify interest- } \\
\text { rate }\end{array}$ \\
\hline Hifdz an Nasl & $\begin{array}{l}\text { To preserve humans, it is } \\
\text { permissible to marry non-Muslims }\end{array}$ & $\begin{array}{l}\text { To preserve humans, the istikharah } \\
\text { method was used by notable figures. }\end{array}$ \\
\hline Hifdz An Nafs & $\begin{array}{l}\text { To maintain health, it is necessary } \\
\text { to consume nutritious food even } \\
\text { if the food is haram or from the } \\
\text { results of haram's dealing }\end{array}$ & $\begin{array}{l}\text { To maintain health, Islam consumes } \\
\text { food which is halaln toyyiban } \\
\text { obtained from halal's dealing }\end{array}$ \\
\hline Hifdz ad-din & $\begin{array}{l}\text { All religions are the same, so it is } \\
\text { necessary to protect other religions } \\
\text { and have a high tolerance. }\end{array}$ & $\begin{array}{l}\text { Religious tolerance does not } \\
\text { necessarily mean mixing different } \\
\text { religious teachings }\end{array}$ \\
\hline
\end{tabular}




\begin{tabular}{ccc}
\hline $\begin{array}{c}\text { Maqosidus } \\
\text { syaria'ah }\end{array}$ & Liberalism & Aswaja-ism \\
\hline Hifdz al irah & $\begin{array}{l}\text { We must maintain the honor and } \\
\text { good name of our fellow humans, Muslims need to be preserved } \\
\text { both Muslims, and non-Muslims }\end{array}$ \\
\hline
\end{tabular}

The data shows that cultural configuration in Islamic boarding schools in higher education in establishing moderate religious academics gives such a way to perceive the internalization of the Islamic boarding school culture. It also supports the movement of formal education during a specific period. Some changes can be initiated from small things to be done by all personnel involved continuously and consistently (istiqomah). Minor changes to the culture at the boarding school will be a significant change when it is carried out continuously by all of the boarding school personnel. In the end, it has become a robust construction. The process of internalizing the values of Islamic boarding schools in higher education can be established as the expectation of the big vision within the pesantren itself.

According to the research results, it can be understood that the cultural construction of Islamic boarding schools in establishing moderate religious academics can be seen as follows: 1) Software of the mind (software of thought) about moderate religious academics. 2) Routine activities related to cognitive, affective, and psychomotor activities. 3) The interaction nodes of moderate religious academics; the interactions between students and students, as well as students and parents, and students and the leaders of pesantren. 4) Practicing Arabic so that it is easier to understand the teachings in the founders' books. 5) Products produced exhibit moderate religious characteristics, such as books that discuss Aswaja's principle. 6) Forms of socialization formal, such as remarks, briefings, lectures, and informal such as examples. 7) The introduction of selfconcept to students as Nahdliyin. 8) Compilation and implementation of the Islamic boarding school's rules related to assessment. 9) Decision-making based on Aswaja's values. 10) An educational system that has an extensive vision and mission based on Islamic boarding schools. 11) Absorption of moderate religious values and norms. 12) Islamic boarding school-based democratic values; from pesantren, by pesantren, and for pesantren. 13) Stories fostered about the character values of kyai and masyaikhs teaching morals based on the values of pesantren. 14) Recruitment of educators having Sunni backgrounds. 14) The books used as references in Islamic boarding schools and high schools are based 
on Aswaja's teachings. 15) Maqosidus syaria'ah characterized based on the values of Aswaja's values

\section{DISCUSSION}

The construction of pesantren's culture in establishing moderate religious academics is carried out through cultural forces. It is an intangible force beyond the one that can be seen (tangible) from an organization, social energy that moves people to behave. Culture for the organization is what is said to be "character" for the individual, something that is hidden, unites, provides meaning, direction, and mobilization. The strength of uswatun hasanah or the role model of leaders, lecturers, lived stories, the spirit of hard work is seen as an intangible culture. It has a sufficiently strong meaning in the cultures of the pesantren.

An overview related to the organizational culture viewed from its features can be visualized as follows:

Table 2. Feature of Artifacts in Pesantren Institutions

\begin{tabular}{cc}
\hline Hardware & Software \\
\hline Ceremonial event & The role model \\
\hline Postering & Kyai's role model \\
\hline Clothing model & Living stories \\
\hline Language & Hard-working \\
\hline Physical appearance & Consistency (Istiqomah) \\
\hline Jargon & Obedience (Tawadlu) \\
\hline Gestures & Zuhud \\
\hline The use of Technology & \\
\hline Esthetical creation &
\end{tabular}

It can be seen that the cultural construction in the internalization of pesantren's culture cannot be separated from two essential aspects, the strength of visible and invisible values. The values of the pesantren concerning the establishment of moderate religious academics in higher education are based on the vision and mission of the pesantren within higher education institutions. Although the naming of the campus does not use the word «Islam," Nurul Jadid University illustrates that the campus stands on Islamic values that emphasize aspects of rahmatan lil alamin.

The aspect of software values that are not visible but can be felt that plays an essential role in the cultural development of Islamic boarding schools in higher education is the value of uswatun hasanah, exemplified by masyayikhs or the 
Islamic scholars in the life of the pesantren. The story brought to life among the community and students related to the figures of the boarding school founder has become a separate construction to introduce and be able to imitate the exemplary aspects of the founding figures within the two Islamic boarding schools.

The Islamic boarding school cultural construction in creating a moderate religious culture in this study is based on three levels as follows: 1) Artifacts, which include structures and processes, both visible and invisible and observable attitudes; 2) Beliefs and values, which include ideas, goals, values, ideological aspirations and rationalization; 3) Basic assumptions, which include beliefs and values received as truth. In this case, attitudes, perceptions, thoughts, and feelings can be determined. Discussing the construction of pesantren's culture in giving birth to a moderate religious culture, of course, is influenced by the ideology of the founder of the masayayikh at the pesantren so that the cultural construction of the pesantren has been maintained until now, even though it is in a simple form. The cultural construction of pesantren in producing moderate religious academics is based on the founders' preaching (dawuh), built through physical and non-physical things. The teaching of KH. Zaini Mun'im, as one of the founders, is articulated through the daily activities of the students. Dawuh is like the term «jimat asl," which deriving meaning such as consistency (istiqomah), independence, trustworthiness, firm, appreciative, noble solutions, and integrity. In addition, the dawuh of the kyai is manifested through the concept of the trilogy and the five awareness of santri.

\section{CONCLUSION}

The construction of Islamic boarding school culture in establishing moderate religious academics at Nurul Jadid Islamic Boarding School and Tebuireng Islamic Boarding School is based on the founder's preach (dawuh) articulated through building artifacts, values, and assumptions. Artifacts in this context are buildings that comprise the aspect of hardware and software in the two boarding schools. It consists of physical buildings, language, technology, creative products, fostered stories. Moreover, there are some ways to show emotions, joint activities, ceremonial events, morale, working programs, rules of conduct, and symbols that have religious and moderate meanings. The values of the pesantren resulted in moderate religious academics cannot be separated from the Aswaja's ideals which are filtered into the values of the pesantren-based values. Meanwhile, the 
construction of mindset encompasses islahiyah, tathawuriyah, and manhajiyah. Moreover, the assumptions made in the establishment of moderate religious academics were the belief system and the ideology of nahdliyah aswaja. 


\section{REFERENCES}

Arikunto, Suharmi. Prosedur Penelitian: Suatu Pendekatan Praktek. 1st ed. Jakarta: Rineka Cipta, 2006.

"Fadly et al. - 2020 - Diagnostic Skill of Internalization-Interconnectio.Pdf," n.d.

Fadly, Wirawan, Fatkul Jannah, Omnia S. Ahmed, and Diah Susanti. "Diagnostic Skill of Internalization-Interconnection Qur'ani With Science in Three Levels of Madrasah." Cendekia: Jurnal Kependidikan Dan Kemasyarakatan 18, no. 2 (December 10, 2020): 267-89. https://doi.org/10.21154/ cendekia.v18i2.2178.

Fahri, Mohamad, and Ahmad Zainuri. "Moderasi Beragama di Indonesia" 25, no. 2 (2019): 6.

Fawaid, Achmad. Kaleidoskop Pondok Pesantren Nurul Jadid,. Probolinggo: Pustaka Nurja, 2019.

Hamid, Abdul, Amran Mahmud, and Aldiawan Aldiawan. "Strategi Dosen Pendidikan Agama Islam dalam Mencegah Ekslusivitas dan Radikalisme Pada Kegiatan Keagamaan Mahasiswa." Halaqa: Islamic Education Journal 3, no. 2 (January 7, 2020): 75. https://doi.org/10.21070/halaqa.v3i2.2724.

Makmun, HA Rodli. "Pembentukan Karakter Berbasis Pendidikan Pesantren: Studi Di Pondok Pesantren Tradisional Dan Modern Di Kabupaten Ponorogo." Cendekia: Jurnal Kependidikan Dan Kemasyarakatan 12, no. 2 (2016): 211-38.

Mundiri, Akmal, and Afidatul Bariroh. "Trans Internalisasi Pembentukan Karakter Melalui Trilogi Dan Panca Kesadaran Santri.” Jurnal Iqra': Kajian Ilmu Pendidikan 3, no. 1 (2018): 24-55.

Nazir. Metode Penelitian. Jakarta: Ghalia, n.d.

Qomar, Mujamil. Manajemen Pendidikan Islam, (strategi Baru Manajemen Pendidikan Islam). 1st ed. Jakarta: Erlangga, 2007.

Ritzer, George. Teori Sosiologis Modern. Jakarta: Prenada, 2004.

Royani, Ahmad. "Eksistensi Pendidikan Pesantren dalam Arus Perubahan." Cendekia: Jurnal Kependidikan Dan Kemasyarakatan 16, no. 2 (November 22, 2018): 387. https://doi.org/10.21154/cendekia.v16i2.1242. 
Schein, Edgah H. Organizational Culture and Leadership. San Fransisco: Jossey Bass Inc, 1992.

Sholeh, Badrus. Budaya damai Komonitas Pesantren,. 1. Jakarta: LP3ES, 2007.

Yusufa, Uun, and Amal Khusna. Penguatan Ma'had al Jamia'ah Sebagai Agen Pengarus Utamaan Moderasi Islam Bagi Santri Di IAIN Jember. Jember: IAIN Jember, 2018. 